\title{
Estimation of gold reserve in Tumakuru district, Karnataka
}

\author{
Zairemmawii \\ Department of Geology, Mizoram University, Tanhril 796004, Mizoram, India \\ Corresponding author: rzairemi@gmail.com
}

\begin{abstract}
Economic value of a country greatly depends on the mineral reserves. India holds the $10^{\text {th }}$ position of gold reserve in the world. It has a large amount of gold reserve in the Pre-Cambrian Dharwar Cratons of the Peninsular India. The study areas lies between latitudes $13^{\circ} 43^{\prime} 0^{\prime \prime}$ to $13^{\circ} 43^{\prime} 35^{\prime \prime} \mathrm{N}$ and longitudes $76^{\circ} 42^{\prime} 55^{\prime \prime}$ to $76^{\circ} 43^{\prime} 15^{\prime \prime} E$ of Tumakuru district of Karnataka, named as GSI (Geological Society of India) Block-F. Gold mineralization is localized within the nose of a large, northerly plunging anticline of a sulphide bearing BIF (banded iron formation) horizon. The main BIF band is over $10 \mathrm{~m}$ thick and is folded into an anticline with a wavelength of over 300 with second order fold (520) near the hinge area. The BIF are overlain by the phyllites (often carbonaceous and pyritic) and greywacke and underlain by meta-andesite and pillow metabasalt. Quartz veins occur within extensional fractures as sigmoidal gash veins in BIF's. Thin alteration zone developed along the contact of the primary chert and iron oxide layers that served as fluids channel ways. Alteration is characterized by chlorite, quartz, calcite, ankerite, sericite, stilpnomelane, pyrrotite, arsenopyrite, pyrite, chalcopyrite, sphalerite and gold replacing and continually grading into layers of weaker iron oxide layers. Litho-logging is done from four borehole, and core samples are used for reserve calculation using reserve estimation calculation method. Cut-off grade for gold is $0.5 \mathrm{~g} /$ tonne. Reserve estimation was done in Block-F within two prominent mineralized zone named as MZ-1 and MZ-2. Based on observation and calculation, the study area contained a high-grade quality and economically productive amount of gold reserve.
\end{abstract}

Key-words: Gold, litho-logging, Pre-Cambrian Dharwar Craton, reserve estimation method.

\section{INTRODUCTION}

India is one of the richest countries in the world in mineral resources. It holds the $10^{\text {th }}$ position of gold reserve in the world and a large amount of its reserve are found in the Pre-Cambrian Dharwar Craton of Penninsular India. As these minerals such as gold has great influence in economy of a country it is therefore mandatory for the government to know at least the total amount of reserve its own country is having. For this reason, reserve estimation of gold is an on-going process till today. The study area lies between the latitudes $13^{\circ} 43^{\prime} 0^{\prime \prime}$ to $13^{\circ}$ $43^{\prime} 35^{\prime \prime} \mathrm{N}$ and longitudes $76^{\circ} 42^{\prime} 55^{\prime \prime}$ to $76^{\circ} 43^{\prime} 15^{\prime \prime} \mathrm{E}$ of Tumakuru District of Karnataka, named as Block-F by GSI (Figure 1).
The study area falls under the Western Dharwar Cratons and consist mainly of meta-volcanic rocks (metaandesite, pyroclastic) and meta-sediments (BIF and argillite-meta greywacke) that are intruded by numerous basic dykes and quartz vein (Bruce Foote, 1882). The investigated area is located $154 \mathrm{~km}$ northwest from the state capital Bengaluru. A great detailed of work has been done in and around the study area in the past. Recent mapping and systematic geological mapping was carried out by Balla (1980), who brought out litho succession followed by Ramakrishnan et al. (1980) as shown in Figure 2 .

The investigated area comprises a sequence of metavolcanics, BIF and meta-argillites-greywacke of the Chitradurga Group of the Dharwar Supergroup which are intruded by granite (Bukkapatna, gabbro dykes and 


\section{GEOLOGICAL MAP OF AJJANAHALLI AREA SHOWING VARIOUS BLOCKS}

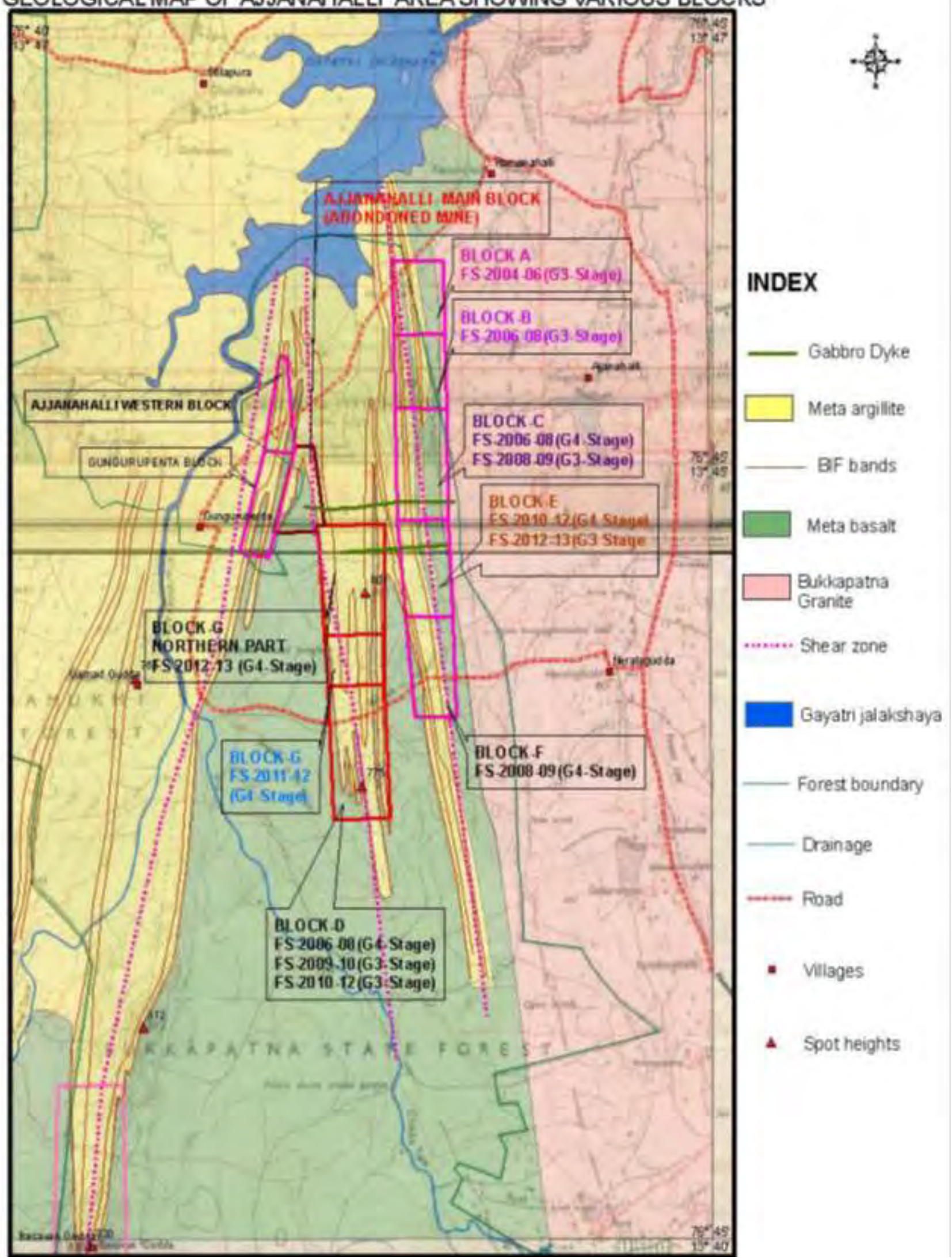

Figure 1: Regional stratigraphy of Western Dharwar Craton (WDC) (after Swami Nath and Ramakrishnan, 1981). 
Figure 2: Regional stratigraphy of Western Dharwar Craton (WDC) (after Swami Nath and Ramakrishnan, 1981).

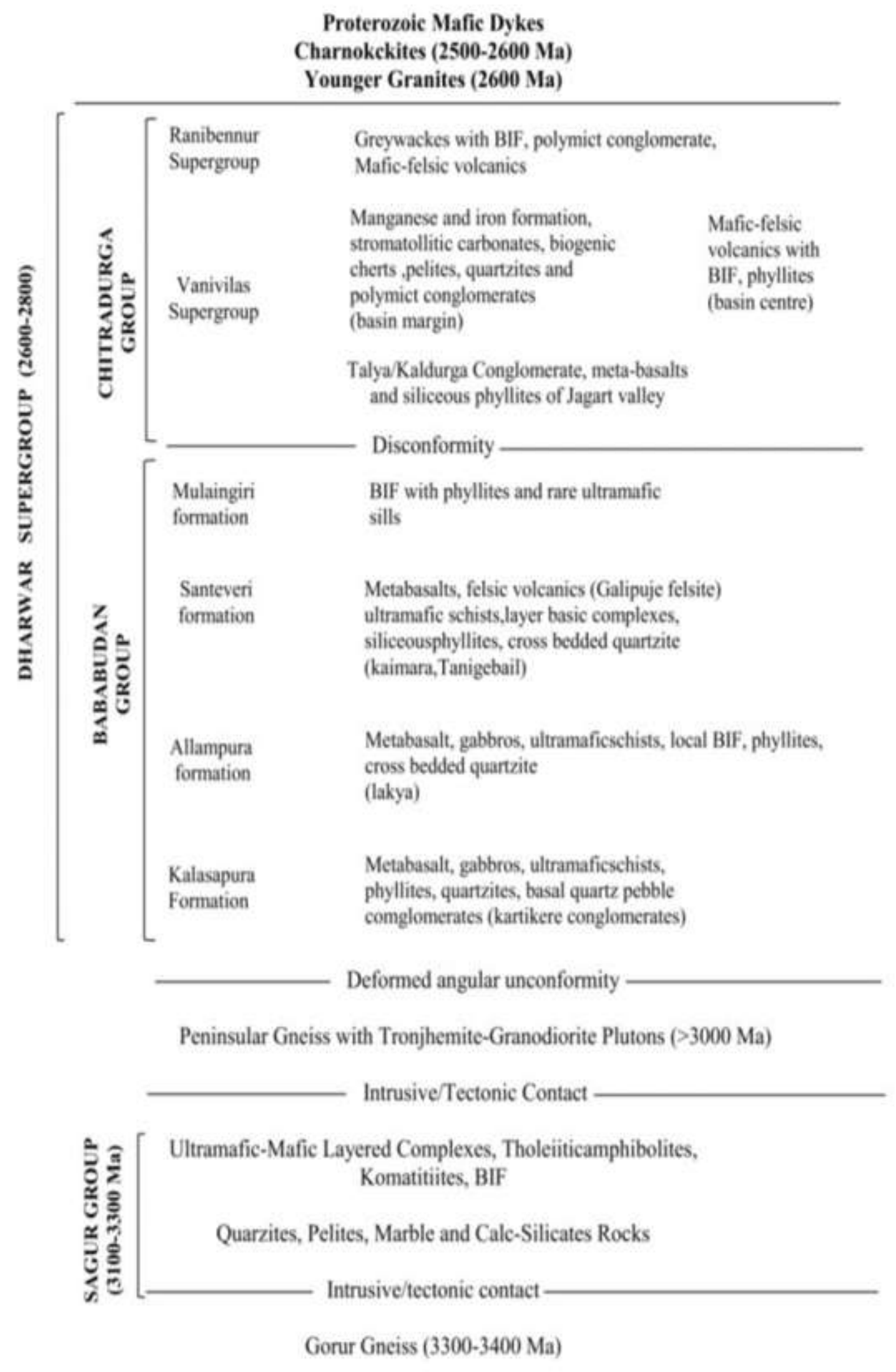




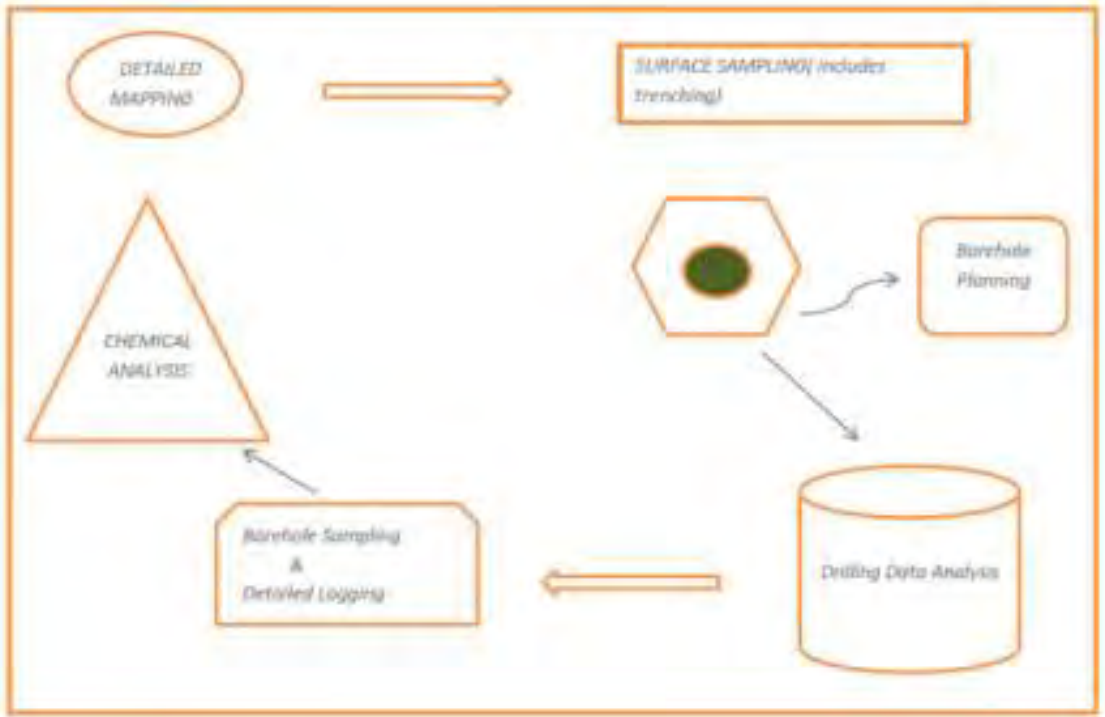

Figure 3: Flow chart representation of exploration.

\section{DETAIL MAP OF PART OF AJJANHALLI GOLD PROSPECT}

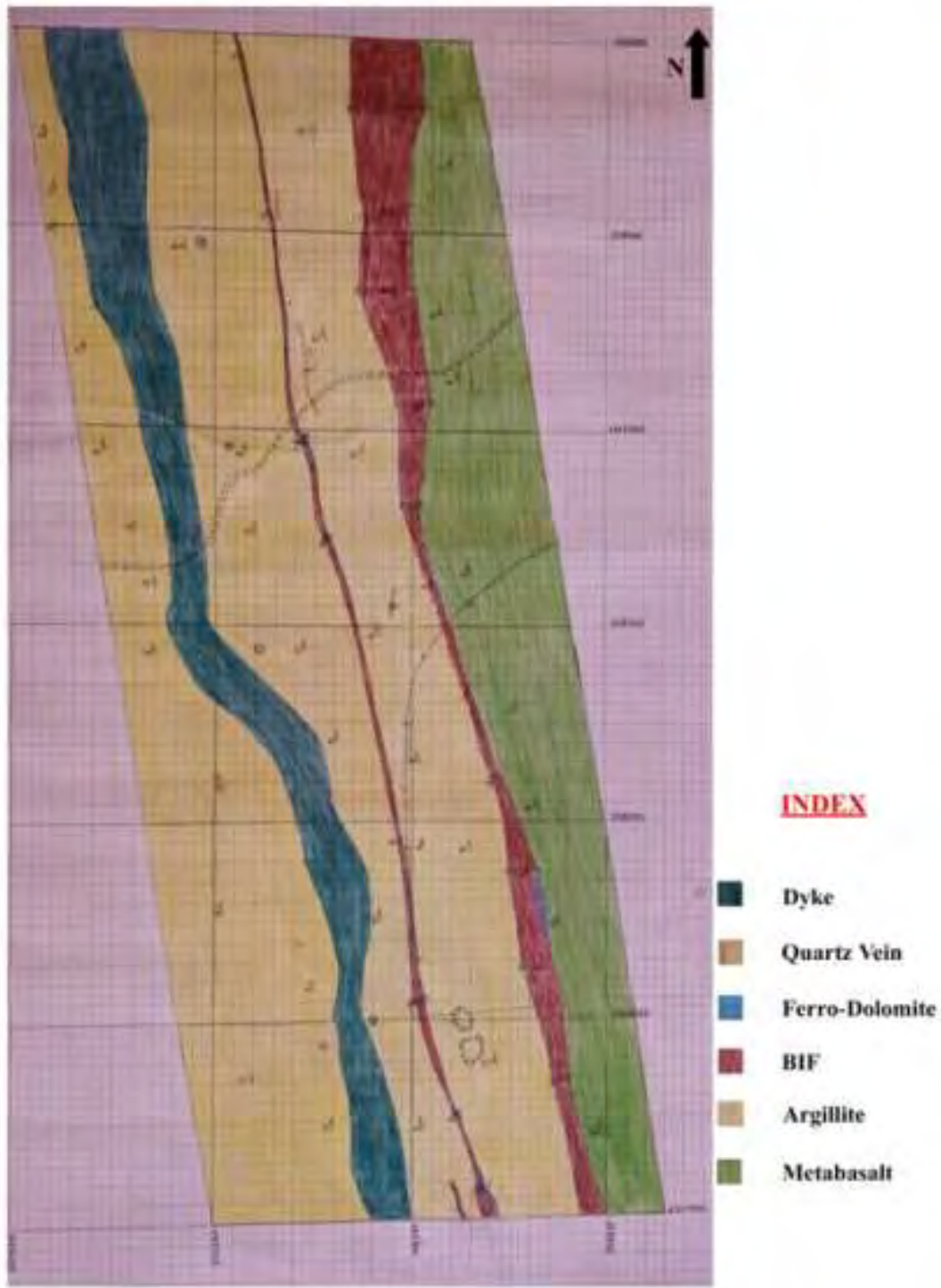

Figure 4: Detailed map of Ajjanahalli Gold Prospect. 
quartz veins). Joints are greatly developed within the gabbroic dykes and in some places highly sheared granite showing $\mathrm{S}-\mathrm{C}$ fabrics are observed. In this F-block the rocks are folded into a steeply plunging antiform. The meta-volcanic rocks occupy the core of the antiform and consist mainly of pyroclastic, pillowed, variolitic and carbonated meta-basalt, thin meta-andesite and impersistent, thin ferro-dolomite.

\section{MATERIALS AND MethodS}

Exploration of any material from the Earth is an art of minimal cost effectiveness along with maximum recovery of the ores and is also succeeded by the events of proper dumping, less hazards in the mine sites, labor welfare and also the non-compromising issues of the environment etc. An effective approach which was carried out during the mapping of the Block-F comprises a sequential event one after another. They can be represented in the form of a flow diagram (Figure 3 ).

For determining the estimation of ore of an area drilling, sampling and geophysical logging are the methods which must be done step by step. Before drilling is done planning of borehole is carefully done. Planning of a borehole is of utmost importance for a geologist concern, since it is an affair involving economy running parallel with the proper crosscutting of the litho units down below. There are some standard criterions for planning of a borehole in an area concerned and they are:

1. A detailed large scale mapping is mandatory so as to carry out a bore hole planning in equal intervals (1:2000).

2. Depending upon the convenience, we took $5 \mathrm{sec}$ tion lines separated by 100 meters and trending E-W.

3. We marked the contours and litho-contacts and also the mineralized zone with other features such as veins and dykes.

4. Plotting the section in a graph paper, we took a scale of $1 \mathrm{~cm}=10 \mathrm{~m}$ and also the dip and foliations are plotted.

5. The profile we thus obtained represents the sections that we will get in a planar view which will be seen if it is vertically chopped out (Figure 3).

6 . Now while plotting a borehole we need to remember certain things, they are

a. Reduced level

b. Dip of lithology

c. Bore hole angle $\left(>45^{\circ}\right)$ since above 45 degrees is considered as for stability and also to carry out a least expensive drilling and also to counter the maximum thickness possible of the lithology or mineralization and also to avoid deviation of B.H.

d. Hence also we get a liberty to maintain another angle to adjust as per convenience

7. In case of gold mining we took $60 \mathrm{~m}$ separation below the ground, to maintain the pressure given by the overburden so that the mine does not collapse on the safety issue as well as least cost of drilling

8. Moreover during cutting or drilling a lithology, we need to extent the drill depth after penetrating the target zone since there is a possibility of getting at the zone of interest.

9. Now after drilling few boreholes we need to take a mean depth or average depth of all to which drill should be done and hence is a finalized drill plan.

10. Other operations like logging and implementing the mine to production phase is to be done later.

After prospecting of the study area of Block-F, drilling is done with the help of a diamond bit rotary drill at 4 places with the total depth of $558.2 \mathrm{~m}$. Borehole cross sections are prepared for each four boreholes (Figures 610). Core samples taken out from the Block-F are kept in a snake or serpent pattern into core boxes (Figure 6).

The cores are analyzed on the basis of several parameters to mark out the zone of interest and are also known as litho-logging. Basically, two types of core logging are carried out from it, firstly, a summarized lithology (Table 1) and secondly a detailed litholog. The main motive that differentiates one from another is their detailed analysis and convincing small scale measurements in the mineralized zone.

The samples are taken from trenches as well as from the borehole core itself. Sampling is basically a process of taking small fraction of a material such that the consistency of that particular portion will serve as a representative fraction of the whole. During the evaluation of grade as well as other commercial parameters, sampling constantly gives homogeneity in characterizing an ore body. Since, we know that ore body comprises a mixture of economic as well as gangue in a non-uniform manner, therefore heterogeneity should be cut out and a systematic distribution is to be done first. Borehole sampling is a subdivision that comes under sub-surface sampling which is again further sub-divided into core, sludge, sidewall sampling, here we concentrate primarily into core sampling only. Now, there involves a sequence of events for preparing a sample. During core sampling, parts with economic interest are treated carefully for further analysis and are reduced depending upon the précised and pre -established norms. Coning and quartering is a process in which the samples are divided into four quadrants of which two of it are taken for laboratory analysis and the remaining two of it are left for future reference.

\section{RESULTS AND DISCUSSION}

Gold mineralization is localized within the nose of a large, northerly plunging anticline of a sulfide-bearing BIF horizon. The main BIF band is over $10 \mathrm{~m}$ thick and is folded into an anticline with a wavelength of over $300 \mathrm{~m}$ with second order folds $(520 \mathrm{~m})$ near the hinge area. The BIFs are overlain by phyllites (often carbonaceous and pyritic) and graywackes and underlain by meta-andesites and pillowed met basalts. The BIFs, especially near the 
Table 1: Summarized litholog of KTAF-4, Block-F, Ajjanahalli, Tumakuru, Karnataka.

\begin{tabular}{|c|c|c|c|c|c|c|c|c|}
\hline \multirow{2}{*}{$\begin{array}{l}\text { Sl. } \\
\text { No. }\end{array}$} & \multirow[t]{2}{*}{ Run } & \multirow[t]{2}{*}{$(\mathbf{m})$} & \multirow{2}{*}{$\begin{array}{l}\text { Width } \\
\text { of the } \\
\text { litho } \\
\text { unit (m) }\end{array}$} & \multirow{2}{*}{$\begin{array}{l}\text { Actual } \\
\text { width } \\
\text { (m) }\end{array}$} & \multirow{2}{*}{$\begin{array}{c}\% \text { of } \\
\text { core } \\
\text { recover } \\
\mathbf{y}\end{array}$} & \multirow[t]{2}{*}{ RQD } & \multirow[t]{2}{*}{ Description } & \multirow{2}{*}{$\begin{array}{c}\text { Core } \\
\text { angle of } \\
\text { litho } \\
\text { contacts }\end{array}$} \\
\hline & & & & & & & & \\
\hline 1 & 0.0 & 9.0 & 0 & 0 & 0 & 0 & $\begin{array}{l}\text { Soil and fragments of rocks mostly of } \\
\text { certified BIF. The nature of soil is sandy in } \\
\text { nature }\end{array}$ & - \\
\hline 2 & 9.0 & 16.4 & 7.4 & 5.45 & $73.64 \%$ & 0 & $\begin{array}{l}\text { Argillite is present. They are very fine } \\
\text { grained and having prominent foliation. } \\
\text { They are partly oxidized and having minor } \\
\text { quartz and carbonate veins }\end{array}$ & - \\
\hline 3 & 16.4 & 18.7 & 2.3 & 2.29 & $99.56 \%$ & $72.8 \%$ & $\begin{array}{l}\text { This unit contains carbon phyllite. } \\
\text { Intercalations of carbon veins are also } \\
\text { present from } 17.43 \mathrm{~m}\end{array}$ & $\begin{array}{c}\text { Arg/Phy } \\
=50^{\circ}\end{array}$ \\
\hline 4 & 18.7 & 37.25 & 18.55 & 18.22 & $98.22 \%$ & $78.19 \%$ & $\begin{array}{l}\text { Argillite is the main lithotype. Some } \\
\text { carbonate and quartz veins are also occurring } \\
\text { along with argillite. From } 22.6 \text { to } 37.25 \mathrm{~m} \\
\text { minor amount of sulphide mineralization is } \\
\text { present. This includes pyrite, chalcopyrite } \\
\text { and arsenopyrite. Nature of the } \\
\text { mineralization is disseminated }\end{array}$ & $\begin{array}{c}\text { Phy/Arg } \\
=50^{\circ}\end{array}$ \\
\hline 5 & 37.25 & 42.90 & 5.65 & 5.64 & $99.82 \%$ & $70.08 \%$ & $\begin{array}{l}\text { Carbon phyllite with chert bands with minor } \\
\text { BIF. This is containing sulphide minerals; } \\
\text { pyrite, arsenopyrite and chalcopyrite in } \\
\text { disseminated nature along the chert bands }\end{array}$ & $\begin{array}{c}\text { Arg/Phy } \\
=40^{\circ}\end{array}$ \\
\hline 6 & 42.90 & 43.40 & 0.5 & 0.5 & $100 \%$ & 0 & $\begin{array}{l}\text { Quartz vein and sulphide minerals are } \\
\text { present }\end{array}$ & $\begin{array}{c}\text { Qtz. } \\
\text { Vein }=35^{\circ}\end{array}$ \\
\hline 7 & 43.40 & 44.60 & 1.2 & 1.2 & $100 \%$ & 0 & Predominantly of BIF and chert & $\mathrm{BIF}=35^{\circ}$ \\
\hline 8 & 44.60 & 46.7 & 2.1 & 2.1 & $100 \%$ & 0 & $\begin{array}{l}\text { Carbon phyllite along the foliation of } \\
\text { phyllite, quartz veins are there which are } \\
\text { hosting sulphide minerals in very less } \\
\text { amount }\end{array}$ & $\begin{array}{c}\mathrm{BIF} / \mathrm{CP} \\
=60^{\circ}\end{array}$ \\
\hline 9 & 46.7 & 49.45 & 2.75 & 2.59 & $94.18 \%$ & $86.54 \%$ & $\begin{array}{l}\text { Argillite with carbonate and quartz veins. } \\
\text { This litho unit is also hosting minor amount } \\
\text { of sulphide minerals (pyrite, chalcopyrite } \\
\text { and pyrrhotite) }\end{array}$ & $\begin{array}{c}\operatorname{Arg} / \mathrm{Mb} \\
=60^{\circ}\end{array}$ \\
\hline 10 & 49.45 & 119.85 & 70.4 & 69.01 & $98.02 \%$ & $87.14 \%$ & $\begin{array}{l}\text { Meta basalt mostly green coloured and } \\
\text { compact along with foliation. Foliations are } \\
\text { occupied by quartz and carbonate veins. } \\
\text { Sulphide minerals also occurred in } \\
\text { disseminated form }\end{array}$ & $\begin{array}{c}\text { Arg/Mb } \\
=60^{\circ}\end{array}$ \\
\hline 11 & 119.85 & 127.24 & 7.39 & 7.36 & $99.59 \%$ & 0 & $\begin{array}{l}\text { Carbon phyllite and certified BIF in alternate } \\
\text { bands. This litho unit is containing } \\
\text { considerable amount of sulphide minerals }\end{array}$ & $\begin{array}{c}\mathrm{Mb} / \mathrm{Cp} \\
=60^{\circ}\end{array}$ \\
\hline 12 & 127.24 & 145.6 & 18.2 & 18.16 & $99.78 \%$ & $84.28 \%$ & $\begin{array}{l}\text { Meta basalt with quartz and carbonate veins. } \\
\text { This unit is partly containing sulphide } \\
\text { minerals too }\end{array}$ & $\begin{array}{c}\mathrm{Cp} / \mathrm{Mb} \\
=60^{\circ}\end{array}$ \\
\hline
\end{tabular}


Figure 5: A diamond (rotary) drilling unit.
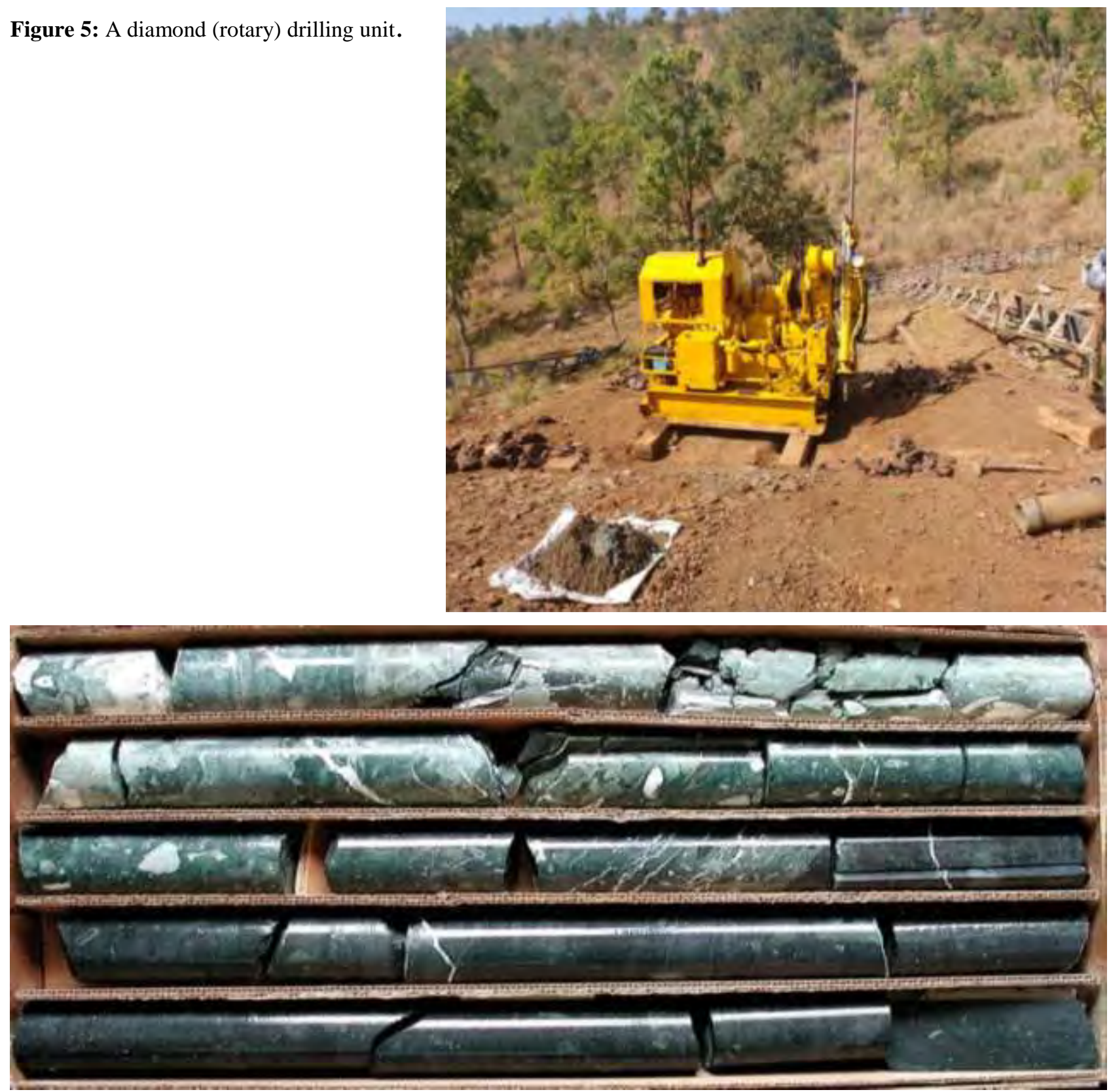

Figure 6: Serpent pattern arrangement of core samples.

hinge of the anticline have been traversed by a number of well-developed small shear zones. The overall sense of shearing in the main and the east reefs is sinisterly and the shearing is synchronous with the $F$, folding event. Cut-off grade can be defined as the minimum grade required in order for a mineral or metal to be economically mined (or processed). Hence it is only or with values above the cut-off grade that is mined. It is expressed as gram/tone. It is to be noted that the distinction between ore and waste cannot be made without a cutoff grade. The cut-off grade for the study area of gold deposit is 0.5 $\mathrm{g} /$ ton. Reserve estimations were done in Ajjanahalli Block
$-F$ within two prominent mineralized zones, viz. MZ-1 and MZ-2. The borehole sections are given below as a measure for reference with the tables of estimation.

\section{Resource Estimation Calculation}

Based on Resource calculation for MZ-I and MZ-II the total resource for $\mathrm{MZ}-\mathrm{I}$ and $\mathrm{MZ}-\mathrm{II}$ are given below:
Total Tonnage:
$0.37 \mathrm{Mt}$
Total metal $(\mathrm{Au})$ :
$586 \mathrm{Kg}$
Average grade:
$1.57 \mathrm{~g} / \mathrm{t}$
Average true width: $\quad 2.71 \mathrm{~m}$

Hence from the above calculation and observation, 


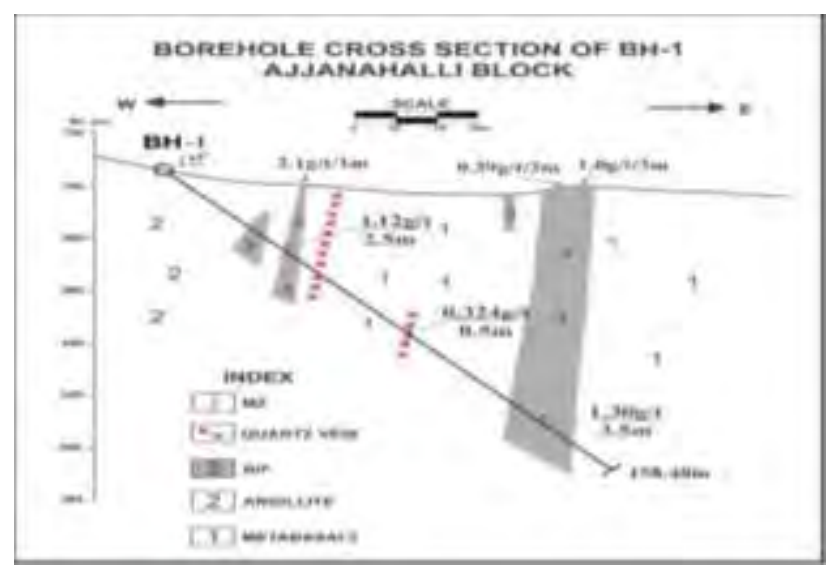

Figure 7: Borehole section of BH-1.

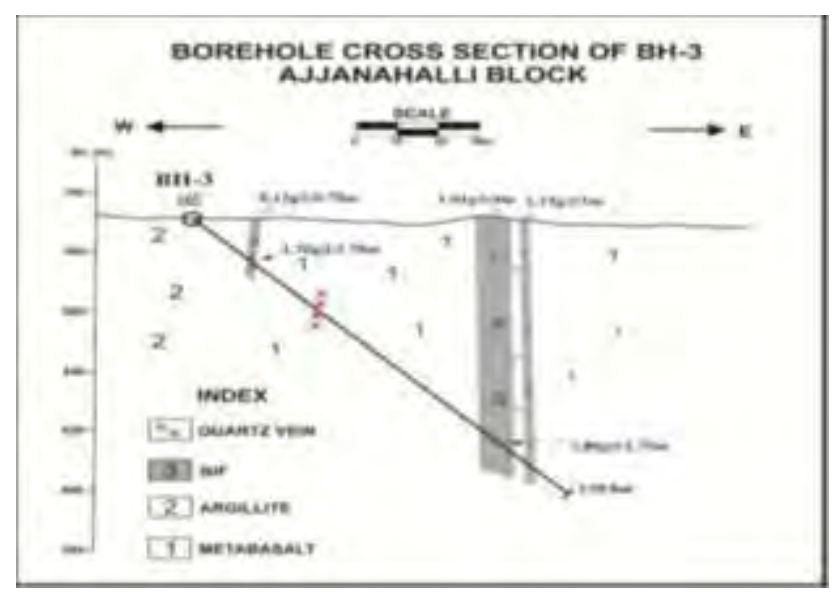

Figure 9: Borehole section of BH-3.

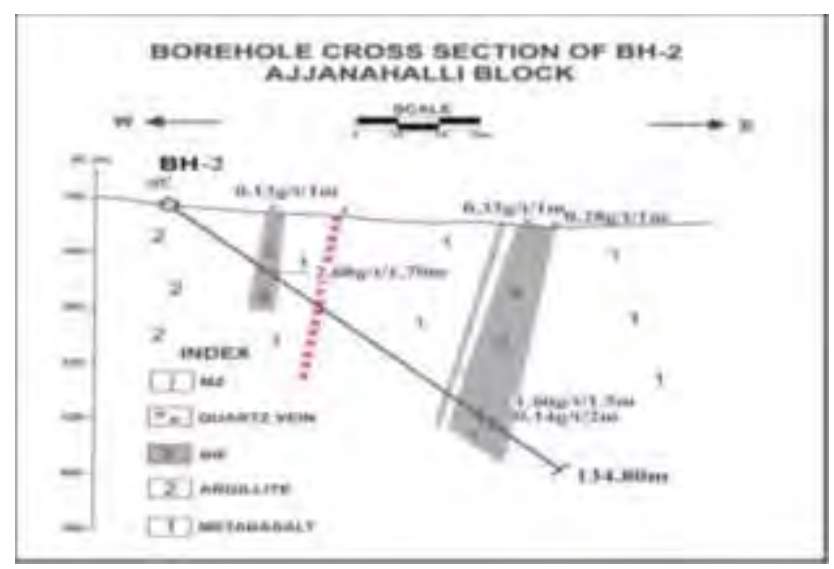

Figure 8: Borehole section of $\mathrm{BH}-2$.

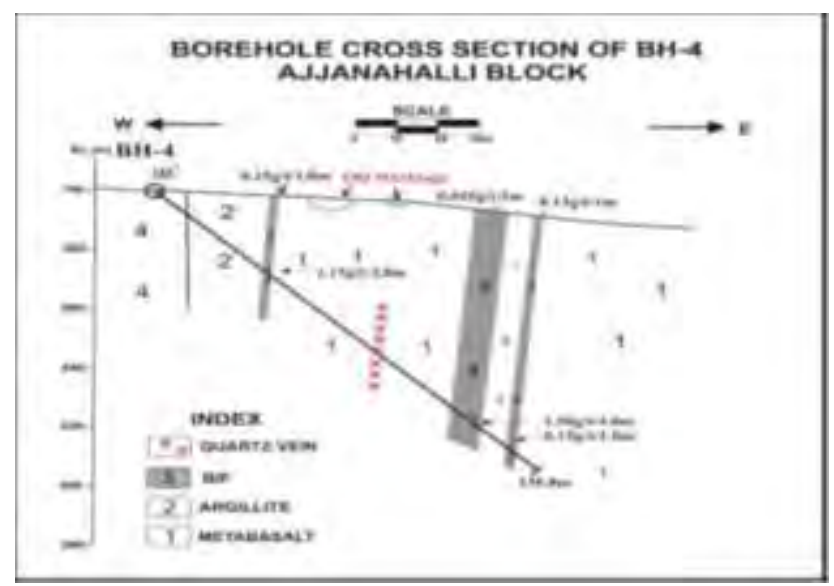

Figure 10: Borehole section of $\mathrm{BH}-4$.

Table 2: Resource estimation of MZ-I of Block-F of Ajjanahalli Area, Tumakuru, Karnataka.

\begin{tabular}{|c|c|c|c|c|c|c|c|c|c|c|}
\hline $\begin{array}{l}\text { BH } \\
\text { No. }\end{array}$ & $\begin{array}{l}\text { MZ } \\
\text { No. }\end{array}$ & $\begin{array}{c}\text { Width } \\
\text { of } M Z \\
\text { in } m(t)\end{array}$ & $\begin{array}{c}\text { Au } \\
\text { assay } \\
(\mathrm{g} / \mathrm{t})\end{array}$ & $\begin{array}{l}\text { Length of } \\
\text { the strike } \\
\text { influence } \\
\text { (m) } \mathrm{L}\end{array}$ & $\begin{array}{c}\text { Length of } \\
\text { MZ along } \\
\operatorname{dip}(H) \text { in } \\
\text { CS (m) }\end{array}$ & $\begin{array}{l}\text { Specific } \\
\text { gravity } \\
\text { (S) }\end{array}$ & $\begin{array}{c}\text { Volume } \\
\text { V=t*L* } \\
\text { H }\end{array}$ & \begin{tabular}{|c|} 
Tonnage \\
$\mathrm{CS} \mathbf{T}=\mathrm{V} * \mathrm{~S}$
\end{tabular} & $\begin{array}{c}\text { Gold content } \\
\text { CS } \\
\mathbf{G}=\mathbf{T}^{*} \mathbf{A}\end{array}$ & $\begin{array}{l}\text { Tonnage } \\
* \text { true width }\end{array}$ \\
\hline $\mathrm{BH} 1$ & 1 & 2.50 & 1.12 & 100 & 60 & 3.15 & 15000 & 47250 & 52920 & 118125 \\
\hline $\mathrm{BH} 2$ & 1 & 1.70 & 2.68 & 100 & 60 & 3.15 & 10200 & 32130 & 86108 & 54621 \\
\hline $\mathrm{BH} 3$ & 1 & 2.70 & 1.30 & 100 & 60 & 3.15 & 16200 & 51030 & 66339 & 137781 \\
\hline $\mathrm{BH} 4$ & 1 & 2.00 & 1.15 & 100 & 60 & 3.15 & 12000 & 37800 & 43470 & 75600 \\
\hline & & 2.30 & 1.48 & & & & & 168210 & 248837.40 & 386127 \\
\hline & & & & & & \multicolumn{2}{|c|}{ Total tonnage } & $0.17 \mathrm{Mt}$ & & \\
\hline & & & & & & \multicolumn{2}{|c|}{ Total metal (Au) } & $249 \mathrm{~kg}$ & & \\
\hline & & & & & & \multicolumn{2}{|c|}{ Average grade } & $1.48 \mathrm{~g} / \mathrm{t}$ & \multicolumn{2}{|c|}{ (grade *tonnage)/tonnage } \\
\hline & & & & & & \multicolumn{2}{|c|}{ Average true width } & $2.30 \mathrm{~m}$ & \multicolumn{2}{|c|}{$\begin{array}{l}\text { (tonnage } * \text { True width) } \\
\text { /tonnage }\end{array}$} \\
\hline
\end{tabular}


Table 3: Resource estimation of MZ-II of Block-F of Ajjanahalli Area, Tumakuru, Karnataka.

\begin{tabular}{|c|c|c|c|c|c|c|c|c|c|c|}
\hline $\begin{array}{l}\text { BH } \\
\text { No. }\end{array}$ & $\begin{array}{l}\text { MZ } \\
\text { No. }\end{array}$ & $\begin{array}{c}\text { Width } \\
\text { of } M Z \\
\text { in } m(t)\end{array}$ & $\begin{array}{c}\text { Au } \\
\text { assay } \\
(\mathrm{g} / \mathrm{t})\end{array}$ & $\begin{array}{l}\text { Length of } \\
\text { the strike } \\
\text { influence } \\
\text { (m) } L\end{array}$ & $\begin{array}{c}\text { Length } \\
\text { of } \mathrm{MZ} \\
\text { along } \\
\operatorname{dip}(\mathrm{H}) \\
\text { in } \mathrm{CS} \\
(\mathrm{m}) \\
\end{array}$ & $\begin{array}{l}\text { Specific } \\
\text { gravity } \\
\text { (S) }\end{array}$ & $\begin{array}{c}\text { Volume } \\
V=t * L * H\end{array}$ & $\begin{array}{c}\text { Tonnage } \\
\text { CS T }=V^{*} S\end{array}$ & $\begin{array}{c}\text { Gold } \\
\text { content CS } \\
\mathbf{G}=\mathbf{T} * \mathbf{A}\end{array}$ & $\begin{array}{c}\text { Tonnage } \\
\text { *true width }\end{array}$ \\
\hline 1 & II & 3.50 & 1.30 & 100 & 60 & 3.15 & 21000 & 66150 & 85995 & 231525 \\
\hline 2 & II & 1.50 & 1.60 & 100 & 60 & 3.15 & 9000 & 28350 & 45360 & 42525 \\
\hline 3 & II & 1.75 & 2.80 & 100 & 60 & 3.15 & 10500 & 33075 & 92610 & 57881.25 \\
\hline 4 & II & 4.00 & 1.50 & 100 & 60 & 3.15 & 24000 & 75600 & 113400 & 302400 \\
\hline & & 3.12 & 1.66 & & & & & 203175 & 337365 & 634331.25 \\
\hline & & & & & & \multicolumn{2}{|c|}{ Total tonnage } & $0.20 \mathrm{Mt}$ & & \\
\hline & & & & & & \multicolumn{2}{|c|}{ Total metal $(\mathrm{Au})$} & $337 \mathrm{~kg}$ & & \\
\hline & & & & & & \multicolumn{2}{|c|}{ Average grade } & $1.66 \mathrm{~g} / \mathrm{t}$ & \multicolumn{2}{|c|}{$($ grade $*$ tonnage)/tonnage } \\
\hline & & & & & & \multicolumn{2}{|c|}{ Average true width } & $3.12 \mathrm{~m}$ & \multicolumn{2}{|c|}{$\begin{array}{l}\text { (tonnage } * \text { True width) } \\
\text { /tonnage }\end{array}$} \\
\hline
\end{tabular}

Table 4: Total resource for the MZ-I \& II.

\begin{tabular}{|c|c|c|c|c|}
\hline MZ No. & $\begin{array}{l}\text { Average width of } \\
\text { MZ in } m(t)\end{array}$ & Average Au assay & $\begin{array}{c}\text { Tonnage CS } \\
\mathbf{T}=\mathbf{V} * \mathbf{S}\end{array}$ & $\begin{array}{c}\text { Gold content } \\
\text { CS } \\
\mathbf{G}=\mathbf{T}^{*} \mathbf{A} \\
\end{array}$ \\
\hline I & 2.30 & 1.48 & 168210 & 248837.40 \\
\hline \multirow[t]{2}{*}{ II } & 3.12 & 1.66 & 203175 & 337365 \\
\hline & 2.71 & 1.57 & 371385 & 586202.40 \\
\hline \multicolumn{2}{|c|}{ Total tonnage } & $0.37 \mathrm{Mt}$ & & \\
\hline \multicolumn{2}{|c|}{ Total metal $(\mathrm{Au})$} & $586 \mathrm{~kg}$ & & \\
\hline \multicolumn{2}{|c|}{ Average grade } & $1.57 \mathrm{~g} / \mathrm{t}$ & & \\
\hline \multicolumn{2}{|c|}{ Average true width } & $2.71 \mathrm{~m}$ & & \\
\hline
\end{tabular}

the study area contained a high grade quality and economically productive amount of gold reserve.

\section{ACKNOWLEDGEMENT}

My obligations are indeed very great to Prof. S.K. Gupta, mentor of my dissertation work in Ajjanahalli Gold Prospect, Karnataka. I would also like to convey my gratitude to Mr. Vijay Kumar, Sr. Geologist, cum field officer and MR. P. Gangaikuppa, Sr. Geologist, Ajjanahalli camp for guiding me throughout my field work. It is my immense pleasure to thank Dr. Laldinpuia PUC, for helping me and guiding me in completing my paper.

\section{REFERENCES}

Arogyaswamy, R.N.P. (1988). Courses in Mining Geology, Fourth Edition. Oxford \& IBH Publishing Co. Pvt. Ltd., pp. 735 .

Ballal, N.R.R (1980), A report on the geology of parts of Chikkanayakanahalli and Sira Taluk, Tumkur district, Karnataka (Unpublished report of GSI).

Ramakrishnan, M., Vaidyanadhan, R. (2010): Geology of India, Volume I. Geological Society of India, Bangalore, pp. 556. 